\title{
Practical experiences in implementing participatory budgets on examples of selected cities in Poland
}

\author{
Katarzyna Szmygin \\ https://orcid.org/0000-0002-5359-6122 \\ k.szmygin@pollub.pl \\ Department of Contemporary Architecture, Faculty of Civil Engineering and Architecture, \\ Lublin University of Technology
}

Olga Górnik

https://orcid.org/0000-0002-6157-6252

gornikolga@gmail.com

Faculty of Architecture, Kraków University of Technology

\begin{abstract}
The article presents the idea of the participatory budget and the course of its subsequent editions in selected cities in Poland - Lublin and Olkusz. Since 2018, participatory budgets have been based on the binding law. For several years now, participatory budgets have played an important role in urban development policy in Poland and have been a part of the public debate on local development with the involvement of residents. The article describes selected parts of the 2018 Act and analyses the development of budgets in Lublin and Olkusz.
\end{abstract}

Keywords: participatory budget, social participation, Lublin, Olkusz

\section{The idea of the participatory budget}

In Poland, the Participatory Budget (PB) was first established in Sopot in 2011. Almost ten years have passed since that event, and the number of cities that decide to implement civic initiatives has been growing every year. The participatory budget is considered to be one of the most dynamically developing civic initiatives. The first editions of the budgets in Polish cities were not based on the legislation, which is why municipalities were organising them on the basis of their own resolutions. Since 2018, all cities with district rights are obliged to introduce such budgets ${ }^{1}$.

The participatory budget is considered as a good form of public involvement. The idea of the participatory budget is the part of the concept of civil society and constitutes a form of public supervision over the actions of local governments ${ }^{2}$. The participatory budgets have played an important role in Poland's urban development policy for several years. It is a special form of social consultations ${ }^{3}$ being part of the public debate on local development with the residents' involvement.

1 The act of 11 January 2018 on amending certain acts to increase the participation of citizens in the process of selecting, operating and controlling some public bodies (Journal of Laws 2018, pos. 130), Art. 1.5.

2 Leksykon budżetowy Sejmu Rzeczpospolitej Polskiej (budgetary glossary of the Sejm of the Republic of Poland, http://www.sejm.gov.pl/ Sejm8.nsf/BASLeksykon.xsp?t=s\&id=667DCF4F24778F74C1257A710030C2E9\&q=bud\%C5\%BCet\%20obywatelski, accessed: 04.2020 .

3 The act of 11 January 2018 on amending certain acts to increase the participation of citizens in the process of selecting, operating and controlling some public bodies (Journal of Laws 2018, pos. 130), Art. 1.3. 
The participatory budget is therefore defined as a dedicated part of a city or municipality budget, allocated to the implementation of initiatives submitted by a local community through direct voting ${ }^{4}$.

Following many years of experience in implementing participatory budgets in Poland and abroad, it is possible to define the benefits of this form of participation. They can be grouped as follows:

- social;

- political;

- educational benefits.

The social benefits of participatory budget consist in changing the role of society in the process of urban development and increasing people's awareness. The residents become active. They have the opportunity to obtain information on other forms of participation in the activities of the local government, such as Zielony Budżet Obywatelski (Civic Green Budget), or social consultations on other initiatives. Learning about the structure of the institutions by the citizens and conducting social consultations oblige the city authorities to be more careful and transparent. This reduces the risk of corruption at local government level. The effect of implementing the participatory budget is to activate socially excluded groups in decision-making processes (the poor, ethnic minorities, people with disabilities, etc.).

The political benefits of the participatory budgeting consist in improved understanding between local authorities and residents. Studies on the effects of the implementation of the participatory budget show that the introduction of the mechanism increases the chances of re-election of the president (mayor, head of district administration) by more than $10 \%^{6}$. In addition, the participatory budget promotes the legitimacy of power and promotes the idea of good governance.

Thanks to the statutory regulations on the distribution of funds from the participatory budget to sub-areas on a municipal scale, the possibility of decentralising finances increases.

The educational benefits, in turn, consist in increasing the knowledge of the citizens about funding, participatory mechanisms, activities of local authorities and distribution of tax funds. The creation of a platform for dialogue between the residents and local authorities raises public awareness and allows to get to know the problems and limitations that city authorities face in their work.

Educating the inhabitants in the field of participation and the possibility of influencing the changes in the city fits in with the idea of sustainable development.

Bearing in mind the sum of the effects, it can be said that the aim of the participatory budgeting is to create a platform for regular cooperation and dialogue between the city authorities and citizens and to involve the citizens in the process of deciding on the distribution of public funds. It should be remembered that projects should cover as many residents as possible. The degree and usefulness in which the selected projects will serve the development of the area depends exclusively on the residents - from the stage of submitting projects to the moment of voting.

\section{Key elements of the Act on amending certain acts to increase the participation of citizens in the process of selecting, operating and controlling some public bodies in the context of a participatory budget}

On 11 January 2018, with the entry into force of the Act on amending certain acts to increase the participation of citizens in the process of selecting, operating and controlling some public bodies ${ }^{7}$, the participatory budget gained the basis in the national system of law. The provisions of the Act created a framework for activities that had been exclusively dependent on the municipality before.

Zielony Budżet Obywatelski (Green Civic Budget) is an initiative launched in 2016 in Lublin, which operates on similar principles to the participatory budget. The share of greenery in projects submitted by residents must be at least $70 \%$.

6 Sorychta-Wojsczyk B., Uwarunkowania wykorzystania budżetu obywatelskiego w administracji publicznej w Polsce, [in:] Zeszyty naukowe Politechniki Sląskiej, no. 1928, 2015, p. 428.

7 The act of 11 January 2018 on amending certain acts to increase the participation of citizens in the process of selecting, operating and controlling some public bodies (Journal of Laws 2018, pos. 130) 
When analysing the provisions of the Act, four important elements can be identified.

The basic assumption of the Act is the obligation to introduce participatory budgets by cities with district rights: the creation of a civic budget is obligatory in municipalities that are cities with district rights ${ }^{8}$. A report ${ }^{9}$ carried out by the Supreme Audit Office showed that most of the 66 cities with district rights had been running participatory budgets even before the Act entered into force.

Another important clause of the law imposes the size of the participatory budget: the value of the participatory budget is at least $0.5 \%$ of the expenditure of the municipality contained in the last submitted report on budget implementation ${ }^{10}$. The report drawn up by the Supreme Audit Office (NIK) shows that three out of eight controlled cities with district rights allocated less than the indicated in the Act $0.5 \%$ of municipal expenditure for this purpose ${ }^{11}$.

The third important clause of the Act entitles every resident of the municipality to vote. The new rules for conducting participatory budgets do not impose any age limits: the rulings of supervisory bodies and administrative courts prohibit the division of residents on the basis of any criterion, such as age or entry in the electoral roll $l^{12}$. This means that a parent or legal guardian of a minor may vote on his or her behalf according to his or her own preferences. If a parent casts a vote on behalf of a 3-year-old child in accordance with his/her preferences, it is difficult to speak of direct voting. This legal state of affairs encourages wider discussion, as it is likely that legal guardians of minors will gain more votes for projects of their choice.

According to the Act, the funds coming from participatory budgets in towns with district rights may be divided into pools covering all or a part of the municipality ${ }^{13}$. Other cities have not received such a possibility. This provision may make it impossible to allocate funds evenly across municipalities. Factors such as the population density of individual parts of the city, the degree of involvement in participation, access to information, and the way in which institutions organise the collection of signatures amplify the disproportions at the stage of submitting projects and then the number of votes.

Due to the Act, a nationwide legal framework regulating the functioning of participatory budgets was created. The clauses of the law organise the rules of operation of the budgets at the national level and give every citizen a chance to vote for a project. This idea is a part of the development strategy of the Polish cities. The universality of the rules gives local governments the opportunity to create the nationwide platform for the exchange of experiences, as well as the unification of the system of evaluation and verification of budgets in cities. Although participatory budgets are not a novelty in Polish cities, evaluation of their legal regulations will be possible only after several years.

\section{The development of the participatory budgets in cities - on the example of Lublin and Olkusz}

The presented examples of Lublin and Olkusz have been selected in such a way as to enable the comparison of the course of the participatory budget in the cities of different scale. In both cities, participatory budgets have already been organised for six years, which makes it possible to compare social involvement in the cities in question.

For the characteristics of the development of the participatory budget in the selected cities, it is worth analysing three elements:

- turnout,

number of completed projects,

allocation for the implementation of projects.

8 Ibidem, Art. 1.5

9 Najwyższa Izba Kontroli (Supreme Audit Office), Funkcjonowanie budżetów partycypacyjnych (obywatelskich). Informacja o wynikach kontroli, Warszawa, 2019, p. 15.

10 Ibidem.

11 Najwyższa Izba Kontroli (Supreme Audit Office), Funkcjonowanie budżetów partycypacyjnych (obywatelskich). Informacja o wynikach kontroli, Warszawa, 2019, p. 15.

12 Dorosz-Kruczyński J., Budżety obywatelskie w gminach na nowych zasadach, [in:] Rzeczpospolita, 12 March 2019 I no. 60 (11303)

13 The act of 11 January 2018 on amending certain acts to increase the participation of citizens in the process of selecting, operating and controlling some public bodies (Journal of Laws 2018, pos. 130), Art. 1.6. 


\section{Lublin}

The authorities of Lublin were among the first in Poland to allocate funds from the city budget for the implementation of civic projects in 2014. President Krzysztof Żuk justified the introduction of the participatory budget as follows:

Recognising that it is the residents who know best what projects are particularly important for their surroundings, every year we allocate funds from the special-purpose reserve for the implementation of investments and renovations in districts [...] This tool is complemented by the Civic Budget, which will allow the residents to directly indicate how to allocate funds from the city budget [...] With its implementation, the residents of Lublin receive another tool allowing them to participate in the process of decision-making about our city ${ }^{14}$.

Table 1 shows the data on the turnout, number of projects and amount of the PBs of the Lublin editions of the participatory budget from 2015.

Table 1. Numerical summary of previous editions of the participatory budget in Lublin, the author's compilation

\begin{tabular}{|c|cccccc|}
\hline & PB 2015 & PB 2016 & PB 2017 & PB 2018 & PB 2019 & PB 2020 \\
\hline $\begin{array}{c}\text { Number of votes cast } \\
\text { Number of persons entitled } \\
\text { to vote }{ }^{15,16}\end{array}$ & $268.1 \mathrm{k}$ & $68 \mathrm{k}$ & $\mathbf{7 3 \mathrm { k }}$ & $38.5 \mathrm{k}$ & $25.5 \mathrm{k}$ & $26 \mathrm{k}$ \\
\hline $\begin{array}{c}\text { Turnout [\%] } \\
\begin{array}{c}\text { Number of implemented } \\
\text { projects }\end{array}\end{array}$ & 17.5 & 25 & 26.8 & 14.2 & 7.5 & 7.9 \\
\hline $\begin{array}{c}\text { Amount for implementation } \\
\text { of projects [PLN] }\end{array}$ & 10000000 & 15000000 & 15000000 & 15000000 & 15000000 & 15000000 \\
\hline
\end{tabular}

The analysis of the previous editions of PB in Lublin shows that their execution is similar to other cities in Poland.

First of all, the turnout is decreasing ${ }^{17}$. In the first three editions of the PBs, the turnout remained at a high (20-25\%) level. Since 2018, a large decline in interest in the project has been observed. In the last two editions of the participatory budget voting, the turnout has fallen to around $7 \%$, despite the abolition of the age limits by the law.

The reason for this may be insufficient promotion of the idea of the participatory budgeting among the city residents. As time passes, the idea loses momentum, which makes promotional activities less intense. Most advertising activities are carried out by groups of urban activists, not by local authorities. Many projects voted for by the residents are not implemented (the reason is the insufficient number of votes), which also translates into a decreasing turnout. The decline in interest in PBs is an issue that requires taking action on the part of the city hall, which should popularise the idea of the civil society, especially among young people.

The amount allocated to the projects remains unchanged - for the fifth time the municipality allocates 15 million PLN for this purpose. The report drawn up by the Miasto2077 shows a close relationship between the size of the participatory budget and turnout - the higher budget amount, the higher the turnout. In the light of this information, the city authorities should discuss whether a higher participatory budget is not be a solution to the alarmingly low turnout in last PB editions in Lublin.

The last element examined is the number of projects implemented. Despite the decreasing turnout, the number of projects is growing every year. This is a nationwide trend, observed mainly in the large cities ${ }^{18}$.

\footnotetext{
14 http://www.lublin.eu/lublin/aktualnosci/10-mln-zl-na-budzet-obywatelski-w-lublinie,1297,66,1.html, accessed: 06.2020.

15 The data presented come from the statistics on the population in Lublin, which are conducted by GUS (General Statistical Office).

16 The summary takes into account the amendments to the regulations, which, from 2019 onwards, allow every citizen of the city, regardless of age, to vote.

17 This trend is visible in most of the larger cities in Poland, after: Redakcja Miasto2077, Raport: Budżet obywatelski w polskich miastach (Participatory budget in Polish cities), March 2019, p. 4.

18 Ibidem, p. 4.
} 
a)

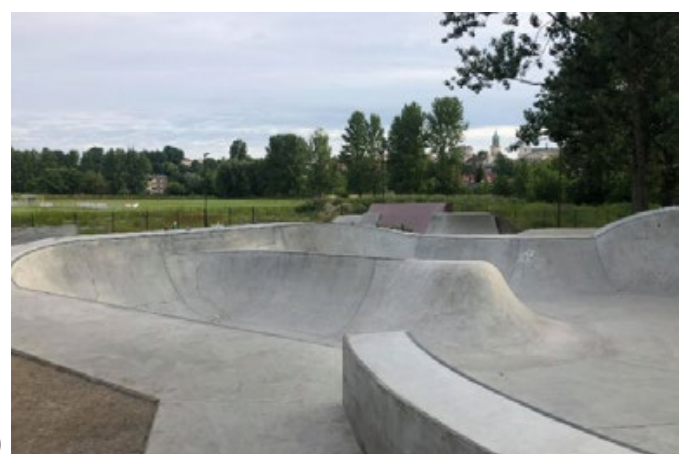

b)

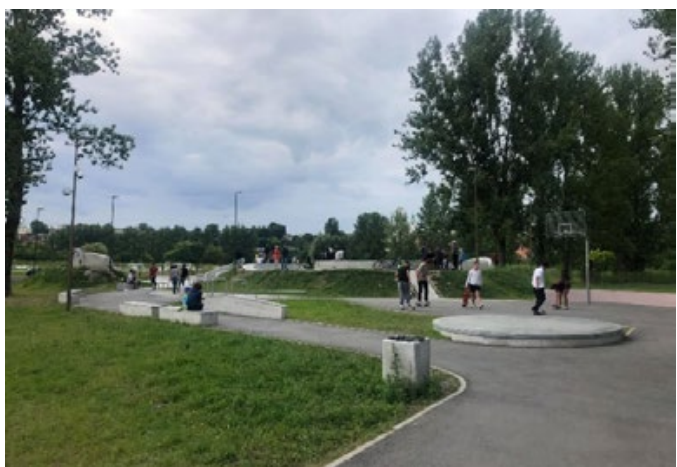

Fig. 1. a, b Skatepark at Rusałka Street in Lublin implemented as part of the participatory budget, author's own photography (July 2020)

a)

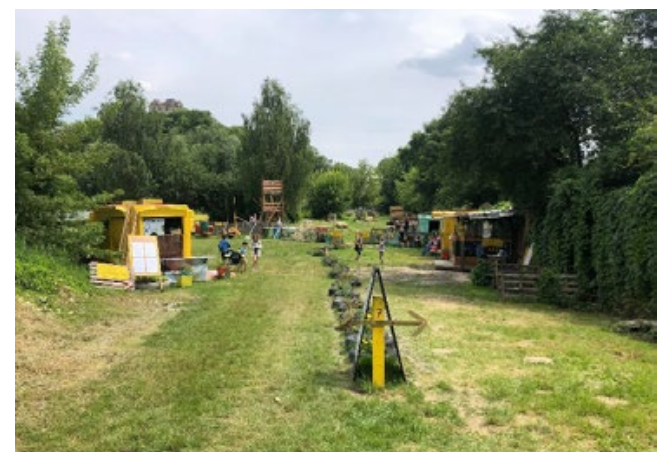

b)

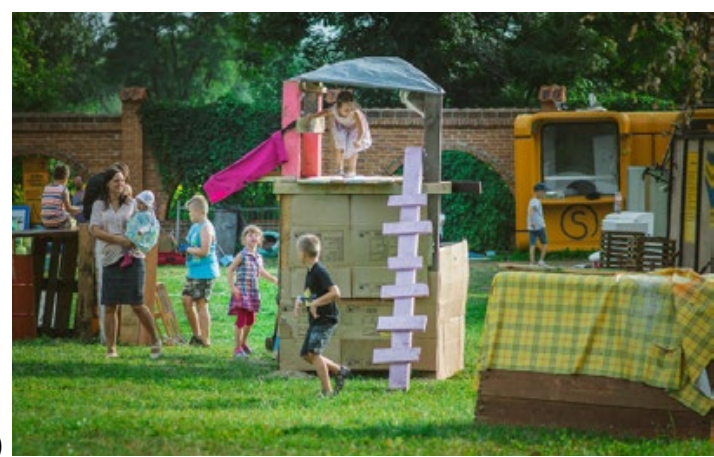

Fig. 2. a - Rezerwat Dzikich Dzieci at Dolna Panny Maria Street in Lublin implemented as part of the participatory budget, author's own photography (July 2020). b - Rezerwat Dzikich Dzieci at Dolna Panny Maria Street in Lublin implemented as part of the participatory budget, author: Rezerwat dzikich dzieci

\section{Olkusz}

The city of Olkusz, like Lublin, has been organising the participatory budget since 2014 .

Table 2 presents the data on the turnout, number of projects, and the amount of PB of the Olkusz participatory budget editions from 2015.

Table 2. Numerical summary of previous editions of the participatory budget voting in Olkusz, author's compilation

\begin{tabular}{|c|c|c|c|c|c|c|}
\hline & & & & & & \\
\hline & PB 2015 & PB 2016 & PB 2017 & PB 2018 & PB 2019 & PB 2020 \\
\hline Number of votes cast & $16 k$ & $14,3 \mathrm{k}$ & $12,3 \mathrm{k}$ & $12,2 \mathrm{k}$ & $12,5 \mathrm{k}$ & $17 \mathrm{k}$ \\
\hline $\begin{array}{l}\text { Number of persons entitled } \\
\text { to vote } \mathrm{e}^{19,20}\end{array}$ & 41026 & 42059 & 41704 & 41360 & 47555 & 47566 \\
\hline Turnout [\%] & 39 & 34 & 29.5 & 29.5 & 26.3 & 35.7 \\
\hline $\begin{array}{l}\text { Number of implemented } \\
\text { projects }\end{array}$ & 11 & 22 & 21 & 21 & 18 & 17 \\
\hline $\begin{array}{l}\text { Amount for implementation } \\
\text { of projects [PLN] }\end{array}$ & 1000000 & 1200000 & 1200000 & 1200000 & 1200000 & 1000000 \\
\hline
\end{tabular}

19 The data presented come from the statistics on the population in Lublin, which are conducted by GUS (General Statistical Office).

20 The summary takes into account the amendments to the regulations, which, from 2019 onwards, allow every citizen of the city, regardless of age, to vote. 
The table shows a high degree of social commitment to the city's affairs. The unchanging turnout of 30-35\% is one of the highest in the whole country. This trend is opposite to that in larger cities, which makes it possible to conclude that the residents of smaller towns are more involved in social participation.

The high turnout is not reflected by the number of implemented projects - the number of implemented projects does not increase.

The Olkusz city authorities have consistently allocated about 1 million PLN to the participatory budget. Just like in Lublin, one should consider whether, with such a high interest in the initiative, the Olkusz city authorities should not increase the amount allocated to the implementation of civic projects.

When analysing the functioning of participatory budgets, we can say that:

- in Lublin (a larger city), the interest in social participation has a downward trend, in Olkusz (a smaller city) it remains at a high level;

- the number of projects implemented in a larger city is increasing, and the number of projects implemented in a smaller city each year remains at a similar level;

- there is no increase in the value of participatory budgets in any of the analysed cities.

\section{Opinion polls}

The analysis of the implementation of the participatory budget is complemented by a survey on the involvement of citizens of Lublin and Olkusz.

The aim of the survey is to learn about the people's knowledge of the participatory budget and their opinion about its course. Such information may be the basis for better decisions to be made in the organisation of PB in the future.

The study was conducted online from March to May 2020. The survey involved people entitled to vote for participatory budgets in the municipalities where it was conducted.

The survey was attended by 100 people - 50 in Lublin and 50 in Olkusz. The respondents answered questions concerning knowledge of the participatory budgeting and level of satisfaction regarding the implementation of the budgets.

Do you know what the participatory budget is?

LUBLIN

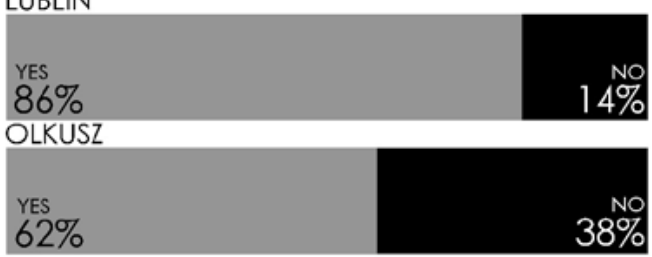

Do you think that the city authorities are making sufficient efforts to inform citizens about the participatory budget initiative?

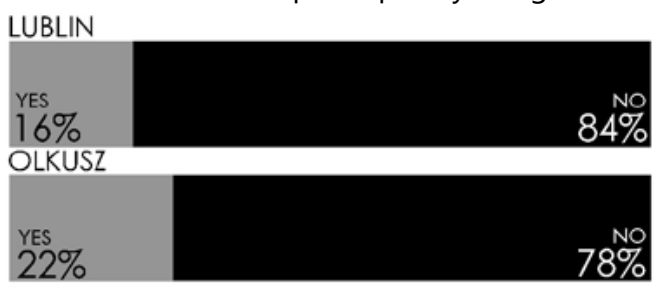


Do you take part in the voting for citizens' projects?

LUBLIN

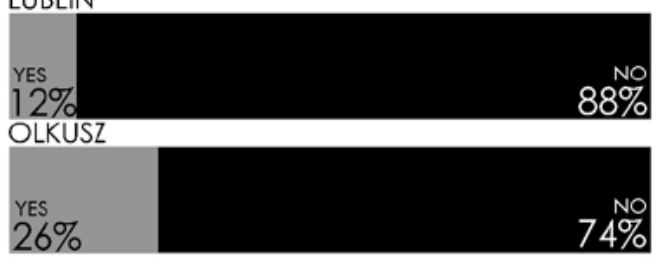

Have you submitted a proposal as part of the participatory budget?

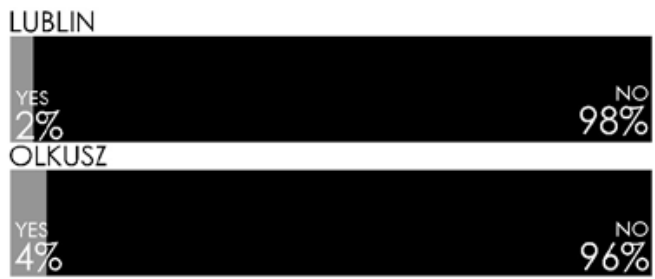

Do you think that the mechanisms of PBs in the city are transparent? LUBLIN

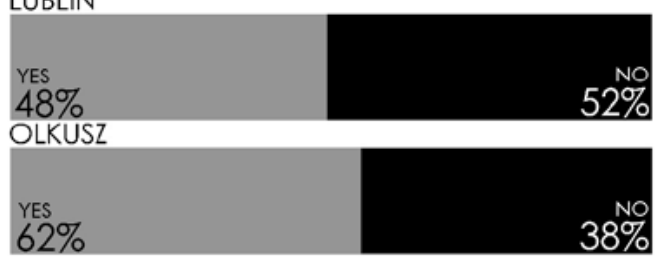

Do you plan to participate in future editions of PSBs?

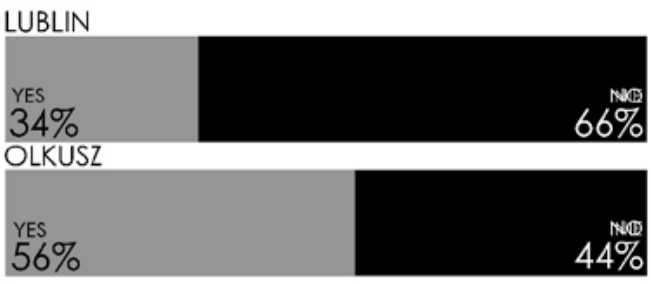

The survey showed a high level of awareness of the principles of the participatory budget among both the residents of Lublin $-86 \%$ and Olkusz $-62 \%$. However, the respondents do not associate their knowledge of participation mechanisms with their popularisation by the local authorities - only $16 \%$ of Lublin residents and $22 \%$ of Olkusz believe that the city authorities make sufficient efforts to inform about the participatory budget. These results provide important information for the local authorities, which should carry out intensified activities aimed at popularising this initiative.

The results of the surveys confirm the turnout statistics carried out by municipalities - $12 \%$ of Lublin's inhabitants and $26 \%$ of Olkusz's inhabitants declared their participation in the participatory budgeting. Only one person in Lublin and two people in Olkusz among the surveyed submitted a project in the participatory budget.

One should ponder why so few people decide to participate in the voting in future editions ( $34 \%$ Lublin, $56 \%$ Olkusz). 


\section{Conclusions}

1. A large number of people take part in the participatory budget, although turnout in larger cities tends to decrease.

2. The residents recognise the importance and usefulness of implementing civic projects - it confirms their willingness to participate in subsequent editions of the budget.

3. The initiative has become a permanent part of the development strategy of the Polish cities.

4. It is necessary to better promote the idea of the participatory budgeting.

\section{References}

[1] Bartkowski J., Tradycje partycypacji w Polsce, [in:] A. Olech (ed.), Partycypacja publiczna. O uczestnictwie obywateli w życiu wspólnoty lokalnej. Instytut Spraw Publicznych, Warszawa, 2011.

[2] Dorosz-Kruczyński J., Budżety obywatelskie w gminach na nowych zasadach, [in:] Rzeczpospolita, 12 March, 2019 I no. 60 (11303).

[3] Fiut K., Górniak A., Krasoń-Pilch K., Kraszewski D., Po co nam budżet obywatelski? Poradnik skutecznej partycypacji dla pracowników samorządowych, Małopolskie Obserwatorium Rozwoju Regionalnego, Departament Polityki Regionalnej (Regional Development Observatory of the Małopolska Region, Regional Development Department), Kraków 2016.

[4] Jendrośka J., Radecki W., Konwencja o dostępie do informacji, udziale społeczeństwa w podejmowaniu decyzji oraz dostępie do sprawiedliwości w sprawach dot. Środowiska, Centrum Prawa Ekologicznego (Environmental Law Center), Wrocław, 1999.

[5] Leksykon budżetowy Sejmu Rzeczpospolitej Polskiej (Budgetary glossary of the Sejm of the Republic of Poland).

[6] Katalog dobrych praktyk europejskich z zakresu zarządzania partycypacyjnego. Fundacja Inicjatyw Menadżerskich, Lublin.

[7] Kębłowski W., Budżet partycypacyjny. Krótka instrukcja obsługi, Warszawa 2013.

[8] Kraszewski D., Mojkowski K., Budżet obywatelski w Polsce, Fundacja im. Stefana Batorego, Warszawa 2014.

[9] Kwiatkowski J., Partycypacja społeczna i rozwój społeczny, Fundacja Rozwoju Demokracji Lokalnej, Warszawa, 2003.

[10] Najwyższa Izba Kontroli, Funkcjonowanie budżetów partycypacyjnych (obywatelskich). Informacja o wynikach kontroli, Warszawa, 2019.

[11] Sorychta-Wojsczyk B., Uwarunkowania wykorzystania budżetu obywatelskiego w administracji publicznej w Polsce [in:] Zeszyty naukowe Politechniki Śląskiej, no. 1928, 2015.

[12] Redakcja Miasto2077, Raport: Budżet obywatelski w polskich miastach (Report: Participatory budget in the Polish cities), March 2019, p. 2.

[13] Regulamin Budżetu Obywatelskiego Miasta Lublin na 2021 rok, §4, https://lublin.budzet-obywatelski.eu/.

[14] Rybińska D., Instytucja budżetu obywatelskiego jako narzędzia rozwoju samorządu lokalnego, [in:] Journal of Finance and Financial Law, Vol. 1(17), March 2018, p. 49-65.

[15] The act of 11 January 2018 on amending certain acts to increase the participation of citizens in the process of selecting, operating and controlling some public bodies (Journal of Laws 2018, pos. 130).

[16] https://www.participatorybudgeting.org/i.

[17] http://www.lublin.eu/lublin/aktualnosci/10-mln-zl-na-budzet-obywatelski-w-lublinie,1297,66,1.html. 